\begin{tabular}{lcc}
\hline Bentham OPEN & The Open Ophthalmology Journal & $\begin{array}{l}\text { The Open } \\
\text { Ophthalmology } \\
\text { lournal }\end{array}$ \\
\hline CrossMark & Content list available at: www.benthamopen.com/TOOPHTJ/ \\
\hline
\end{tabular}

\title{
Ocular, Neurologic and Systemic Findings of the Cases with Optic Nerve Hypoplasia
}

\author{
Eyyup Karahan ${ }^{1, *}$ and Ayse Tulin Berk ${ }^{2}$ \\ ${ }^{I}$ Sifa University, Department of Ophthalmology, Izmir, Turkey \\ ${ }^{2}$ Dokuz Eylul University, Department of Ophthalmology, Izmir, Turkey
}

\begin{abstract}
:
Aim:

To describe the associated ocular, neurologic, and systemic findings in a population of children with optic nerve hypoplasia (ONH) and to evaluate the relationship between ocular signs and neurologic findings.

\section{Method:}

A retrospective chart review of 53 patients with the diagnosis of ONH seen between December 1998 and September 2012 was performed. All neurodevelopmental anomalies, neuroradiologic findings, endocrinologic and systemic findings were recorded. Poor vision was defined as the visual acuity poorer than $\log$ MAR 1.0 or inadequate central steady maintained fixation.

\section{Results:}

Thirty (56.6\%) of the 53 children with ONH were boys. Mean age at presentation was $56.2 \pm 46.8$ months (range; 3 months to 18 years). Poor vision defined for the purpose of this study was found in $47.2 \%$ of 53 patients. Thirty-three (62.3\%) children had nystagmus. Thirty-four (64.2\%) children had strabismus. Thirteen (38.2\%) of those with strabismus had esotropia, $20(58.8 \%)$ had exotropia. The total number of the children with neurodevelopmental deficit was $22(41.5 \%)$ in our study.
\end{abstract}

\section{Conclusion:}

The vision of young children with ONH should be monitored at least annually, and any refractive errors should be treated. Neuroimaging of the brain and endocrinologic evaluation is necessary in all cases with ONH.

Keywords: Endocrinologic evaluation, neurodevelopmantal anomaly, neuroimaging, optic nerve hypoplasia.

\section{INTRODUCTION}

Optic nerve hypoplasia (ONH) is an ocular malformation diagnosed clinically on the basis of an abnormally small optic nerve head. Additional ophthalmoscopic features include optic nerve pallor, the "double-ring sign," (Fig. 1) and tortuous retinal vessels. It may occur unilaterally or bilaterally, and the lost of nerve tissue can be diffuse or segmental $[1-4]$.

It is histologically characterized by a subnormal number of optic nerve axons and is an nonprogressive, nonspecific manifestation of damage at any site of the visual pathways, sustained anytime before its full development [5 - 8]. It may cause a wide range of visual disabilities, and a high frequency of associated central nervous system abnormalities in children with ONH, indicating the complexity of this diagnosis [9 - 11]. Optic nerve hypoplasia has been associated with a broad range of congenital intracranial anomalies, including absence of the septum pellucidum, thinning of the

\footnotetext{
* Address correspondence to this author at the Narlı Mah Ecem Sok 42C/7, Narlıdere, 35330, Izmir, Turkey; Tel: 90 232 278 8111; Fax: 90 232 278 6804; E-mail: karahaneyup@yahoo.com
} 
corpus callosum, and dysplasia of the anterior third ventricle in septo-optic dysplasia (De Morsier syndrome), posterior pituitary ectopia, and cerebral hemispheric malformations [11].

Although it is very well known that $\mathrm{ONH}$ is associated with neurologic, endocrinologic and other systemic disorders some authors recommend that only children with bilateral ONH, nystagmus, and poor vision should undergo a thorough neuroradiographic and endocrine examination. Skarf and Hoyt [2] stated that scanning is not indicated unless the child shows clinical evidence of either hormone deficiency or a congenital anomaly. However, to perform neuroimaging and endocrinologic investigation in all cases with $\mathrm{ONH}$ is another approach [12,13].

The purpose of the present study was to describe the associated ocular, neurologic, and systemic findings in a population of children with ONH and to evaluate the relationship between ocular signs and neurologic findings.

Table 1. Characteristics of the patients $[\mathrm{n}(\%)]$.

\begin{tabular}{|c|c|}
\hline & All Subjects (n=53) \\
\hline Age at examination & $3(5.6)$ \\
$<6$ months & $8(15.2)$ \\
$6-12$ months & $21(39.6)$ \\
$2-5$ years & $21(39.6)$ \\
$>5$ years & $18(33.9)$ \\
\hline Type of the refraction & $12(22.6)$ \\
Emmetropia & $9(16.9)$ \\
Hyperopia & $8(15.1)$ \\
High hyperopia & $6(11.3)$ \\
Myopia & $21(39.6)$ \\
High myopia & $32(60.1)$ \\
\hline Cylindiric refraction & $33(62.3)$ \\
$\geq 1$ dioptry & $20(37.7)$ \\
\hline Nystagtry & $19(35.9)$ \\
Yes & $13(24.6)$ \\
No & $20(37.7)$ \\
\hline Type of the strabismus & $1(1.8)$ \\
\hline Ortophoric & \\
\hline Esotropia & \\
Hypertropia & \\
\hline
\end{tabular}

\section{METHODS}

A retrospective chart review of 53 cases with the diagnosis of ONH seen between December 1998 and September 2012 was performed, with information regarding age at first examination, diagnosis (ophthalmologic and others), visual acuity, cycloplegic refraction, orthoptic condition, and fundoscopic findings being extracted from the medical files. All neurodevelopmental anomalies, neuroradiologic findings, endocrinologic and systemic findings were also recorded. As all the study cases were minors, their parents gave written informed consent prior to participation in conformity with the Declaration of Helsinki.

Snellen visual acuity was recorded whenever possible. In younger or less cooperative cases, Teller acuity cards testing or the ability to "fixate and follow" a target was used. Best corrected visual acuity (BCVA) values measured using Snellen chart and Teller acuity cards (corresponding visual equivalents were initially measured according to the manufacturer using the conversion scale placed on each cards) were converted into logMAR unit for statistical analysis. Poor vision was defined as the visual acuity worse than logMAR 1.0 or inadequate central steady maintained (CSM) fixation while normal vision was defined as the visual acuity equal or better than logMAR 1.0 as well as positive CSM [12].

In $56.2 \%$ of the study population, BCVA could be measured using Snellen chart and Teller acuity cards. Those with light perception or no visual-orienting behavior were arbitrarily given an acuity of 0.13 and 0.10 cycles/degree, respectively [14].

Cases whose visual acuity could be evaluated with CSM fixation did not include to parametric statistical analysis. In 9 of the 49 bilateral cases visual acuity was different in 2 eyes, the eye with poorer visual acuity was used for statistical analysis. In cases with similar visual acuity the refraction of the eye with higher spherical equivalent was used for statistical analysis. Orthoptic examination was performed with prism cover test or Hirschberg and Krimsky tests 
depending on the cooperation level of the case. Restriction of ocular motility as well as the presence of nystagmus and its type were noted. Cycloplegia was accomplished with one drop of $1 \%$ cyclopentolate and 1\% tropicamide, repeated in five to ten minutes, with retinoscopy performed after 45 minutes. To find out the refractive errors, retinoscopy was performed in all patients and confirmations were provided via autorefractometry (Retinomax; Right Manufacturing, Virginia Beach, VA) if possible.

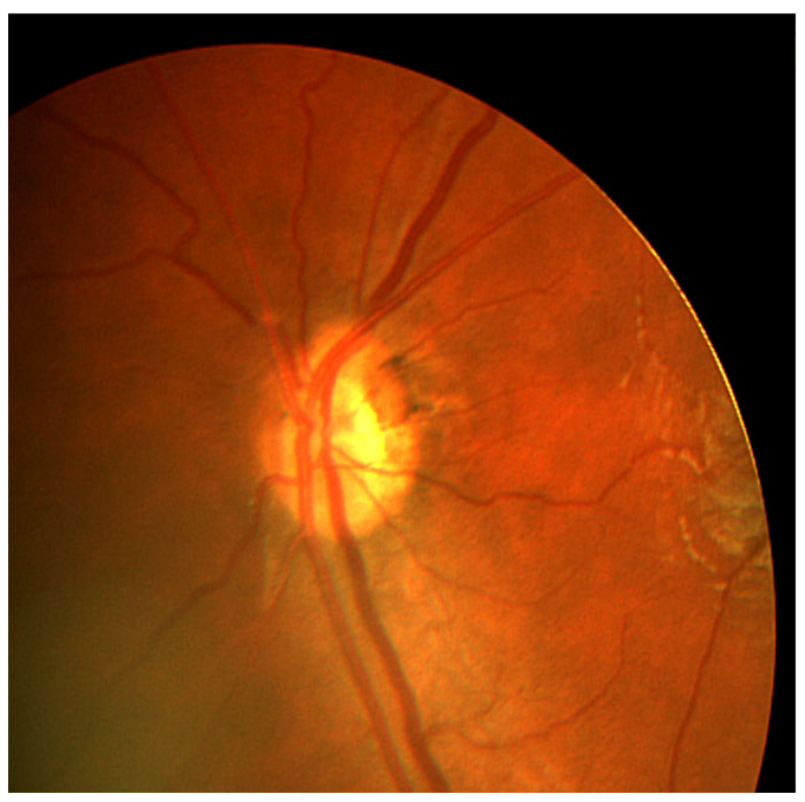

Fig. (1). An eye with optic nerve hypoplasia and double-ring sign.

Spherical equivalents, found by adding the half of cylindrical values to spherical values, were used in comparisons. In 49 bilateral cases, cases were assessed as emmetropic if between 0.75 diopters of myopic and hypermetropic equivalents, hyperopic if between +1.0 and +4.75 diopters, highly hyperopic if +5.0 diopters and above, myopic if between -1.0 and -4.0 diopters, and highly myopic if -4.25 diopters and above.

SPSS, statistical software, version 11.6 (SPSS, Inc., Chicago, IL, USA) was used for statistical analysis. Normality of the datas was evaluated with Kolmogorov-Smirnov test. The categorical variables between the groups were analyzed by using $\chi 2$ test. Mann Whitney U test was used to compare non-categorical variables. P value of less than 0.05 was considered statistically significant.

\section{RESULTS}

Thirty (56.6\%) of the 53 cases with ONH were boys. Forty-nine (92.4\%) of the cases had bilateral ONH. Mean age at ophthalmologic examination was $56.2 \pm 46.8$ months (range; 3 months to 18 years). Mean spherical equivalent was $0.51 \pm 3.43$ dioptry (range:-8.25 to +8.5 dioptry). Thirty-three $(62.3 \%)$ cases had nystagmus, none of the cases with unilateral ONH had nystagmus. Thirty-four $(64.1 \%)$ of the cases had strabismus. Characteristics of the 53 cases are shawn in Table $\mathbf{1}$.

Visual acuity could be assessed with the Snellen chart in 21 cases (39.6\%), and with the Teller acuity cards in 8 cases $(15.1 \%)$, whereas optokinetic nystagmus or CSM was taken into account according to the bilateral fixation pattern in the remaining 24 cases $(45.3 \%)$. The mean best-corrected visual acuity of cases that could be measured using Snellen chart or Teller acuity cards was found as $\log$ MAR $0.52 \pm 0.40,11$ eyes had no light perception, 5 eyes had motion perception, 8 eyes had CSM fixation. Poor vision defined for the purpose of this study was found in $47.2 \%$ of 53 cases. Table 2 demonstrates the comparement of the cases with and without poor vision. Multiple regression analysis revealed that, the only important factor on BCVA was the presence of neurodevelopmental anomaly.

One case had ptosis, one case had Duane Syndrome Type 1. Two cases had albinism, iris transillumination defect and foveal hypoplasia. One case had punctual atresia and microcornea.

Total case number with neuro-developmental deficit was 22 in our study (41.5\%). All of the 22 cases had bilateral $\mathrm{ONH}$ and none of the cases with unilateral ONH had neurodevelopmental deficit. Developmental delay was the most 
common neurologic associated finding and was present in $13(24.5 \%)$ cases, there were $4(7.5 \%)$ cases with cerebral palsy in our population. Three cases $(5.6 \%)$ had seizure disorder. One case had Dandy Walker anomaly, and 1 case $(1.9 \%)$ had Silver Russel Syndrome. Table 3 shows ocular findings in the cases with and without neurodevelopmental anomaly.

Table 2. Characteristics of the patients who had vision $<\log$ MAR 1.0 or inadequate CSM fixation and patients who had vision $\geq \log M A R 1.0$ or positive CSM fixation $[n(\%)]$.

\begin{tabular}{|c|c|c|c|}
\hline & $\begin{array}{c}\text { Vision }<\log \text { MAR } 1.0 \text { or Inadequate } \\
\text { CSM Fixation }(n=25)\end{array}$ & $\begin{array}{l}\text { Vision } \geq \log \text { MAR } 1.0 \text { or Positive } \\
\text { CSM Fixation }(n=28)\end{array}$ & P Value \\
\hline Mean spherical equivalent (Dioptry) & $0.33 \pm 3.33$ & $0.75 \pm 3.62$ & 0.665 \\
\hline $\begin{array}{c}\text { Spherical Refractive Error } \\
\text { Emmetropia } \\
\text { Hyperopia } \\
\text { High hyperopia } \\
\text { Myopia } \\
\text { High Myopia }\end{array}$ & $\begin{array}{l}9(36.0) \\
6(24.0) \\
6(24.0) \\
1(4.0) \\
3(12.0)\end{array}$ & $\begin{array}{l}9(32.1) \\
6(21.4) \\
3(10.7) \\
7(25.0) \\
3(10.7)\end{array}$ & 0.253 \\
\hline $\begin{array}{c}\text { Cylindiric Refractive Error } \\
\quad<1 \text { Dioptry } \\
\geq 1 \text { Dioptry }\end{array}$ & $\begin{array}{c}9(36.0) \\
16(64.0)\end{array}$ & $\begin{array}{l}12(42.9) \\
16(57.1)\end{array}$ & 0.610 \\
\hline $\begin{array}{l}\text { Nystagmus } \\
\text { Yes } \\
\text { No }\end{array}$ & $\begin{array}{l}11(44.0) \\
14(56.0)\end{array}$ & $\begin{array}{l}19(67.9) \\
9(32.1)\end{array}$ & 0.080 \\
\hline $\begin{array}{l}\text { Strabismus } \\
\text { Yes } \\
\text { No }\end{array}$ & $\begin{array}{l}15(60.0) \\
10(40.0)\end{array}$ & $\begin{array}{l}10(35.7) \\
18(64.3)\end{array}$ & 0.748 \\
\hline $\begin{array}{c}\text { Neurodevelopmental anomaly } \\
\text { Yes } \\
\text { No }\end{array}$ & $\begin{array}{l}13(52.0) \\
12(48.0)\end{array}$ & $\begin{array}{c}9(32.1) \\
19(67.9)\end{array}$ & 0.143 \\
\hline
\end{tabular}

Twenty-five (47.8\%) of the cases underwent neuroimaging, 22 of them had MRI and 3 had computed tomography. Five $(20 \%)$ of these 25 cases had normal scans. Four cases had hypoplasia of corpus callosum. Eleven cases had cortical atrophy, one case had partial hydrancephaly, cerebellar atrophy, ventriculomegaly and also corpus callosum hypoplasia, one case of which has unilateral ONH had Chiary 1 Malformation (sphenoid meningosel, cerebello-toncillary ectopia) and hypophisial gland displacement, this case had also morning glory malformation in his left eye, dismorfic face, left ptosis and haemongioma at right eyelid and one case had cerebral interdigitation. Two cases had septo-optic dysplasia.

Endocrine deficits were detected in $2(3.7 \%)$ cases. Both of them had growth hormone deficiency. One of them had hypophyseal ectopia on cranial MRI imaging.

Two cases had a history of premature birth. One case had cardiomegaly and macroglossy. One had rectal agenesia, and one patient had cleft palate. Three parents were second degree relatives.

\section{DISCUSSION}

Optic nerve hypoplasia, is the most common congenital anomaly of the optic disc. It may be an isolated finding or part of a spectrum of anatomical and functional abnormalities, which include partial or complete agenesis of the septum pellucidum, other midline brain defects, cerebral anomalies, pituitary dysfunction, and structural abnormalities of the pituitary gland [15 - 20].

There seems to be a slight predominance of boys in ONH, varying in proportion from $56 \%$ to $75 \%$ [15, 19, 21, 22]. This preponderance of boys was also found in this study $(56.6 \%)$.

There have been varying reports in the literature regarding visual function among children with ONH, ranging from normal vision to a high frequency of children who can only perceive light or have no light perception [10, 19, 23 - 25]. In a study of 35 children with bilateral $\mathrm{ONH}$, more than half of the eyes had visual acuity in the range of light perception or no light perception, $86 \%$ had acuity less than $20 / 200$, and $80 \%$ were legally blind [19]. In our study 25 $(47.2 \%)$ of the casess had poor vision. Multiple regression analysis revealed that the only important factor that effects the visual acuity was the presence of associated neurodevelopmental anomaly. It should be noted that 17 of 25 cases with severe visual impairment were younger than 3 years and the visual testing in this age group is unreliable. In addition, it has been shown that cases with ONH may have delayed visual maturation [26]. 
There are varying reports in the literature regarding refraction abnormalities among children with ONH, and a high proportion of myopia (23\% over 4 D) has been reported [27]. However, in a study 40 eyes were reported on in which the refractive state has been recorded thus the spherical and cylindrical components were distributed as in the general population [28]. In the current study, fourteen eyes (26.4\%) had myopic total spherical power, whereas 21 eyes (39.6\%) had hyperopic total spherical power and 18 eyes (33.9\%) had spherical power lower than 0.75 D. Six of the 14 myopic eyes had myopia greater than $4 \mathrm{D}, 9$ eyes of the 21 hyperopic eyes had hyperopia greater than $4.75 \mathrm{D}$. Although our study revealed a slightly higher range of hypermetropia, it is not possible to conclude that cases with ONH have hypermetropia more than myopia because age matched normal subjects that also had a tendency to have hypermetropia.

Table 3. Ocular findings in the patients with and without neurodevelepmental anomaly [n(\%)].

\begin{tabular}{|c|c|c|c|}
\hline & Isolated ONH (n=31) & ONH with Neurodevelopmental Anomaly $(\mathrm{n}=22)$ & $\mathbf{P}$ \\
\hline Spherical equivalent & $0.33 \pm 3.34$ & $0.75 \pm 3.62$ & 0.871 \\
\hline $\begin{array}{c}\text { VA } \\
\text { Poor } \\
\text { Not poor }\end{array}$ & $\begin{array}{l}12(38.7) \\
19(61.3)\end{array}$ & $\begin{array}{c}13(59.1) \\
9(40.9)\end{array}$ & 0.143 \\
\hline \begin{tabular}{|c|} 
Spherical Refractive Error \\
Emmetropia \\
Hyperopia \\
High hyperopia \\
Myopia \\
High Myopia \\
\end{tabular} & $\begin{array}{l}9(29.0) \\
9(29.0) \\
4(12.9) \\
6(19.4) \\
3(9.7)\end{array}$ & $\begin{array}{l}9(40.9) \\
3(13.6) \\
5(22.7) \\
2(9.1) \\
2(13.6)\end{array}$ & 0.834 \\
\hline Astigmatic power & $1.26 \pm 0.97$ & $1.22 \pm 1.47$ & 0.886 \\
\hline $\begin{array}{c}\text { Cylindiric Refractive Error } \\
<1 \mathrm{D} \\
\geq 1 \mathrm{D} \\
\end{array}$ & $\begin{array}{l}14(45.2) \\
17(54.8)\end{array}$ & $\begin{array}{c}7(31.8) \\
15(68.2)\end{array}$ & 0.328 \\
\hline $\begin{array}{l}\text { Nystagmus } \\
\text { Yes } \\
\text { No }\end{array}$ & $\begin{array}{l}18(58.1) \\
13(41.9)\end{array}$ & $\begin{array}{l}12(54.5) \\
10(45.5)\end{array}$ & 0.799 \\
\hline $\begin{array}{l}\text { Strabismus } \\
\text { Yes } \\
\text { No }\end{array}$ & $\begin{array}{l}19(61.3) \\
12(38.7)\end{array}$ & $\begin{array}{c}14(63.6) \\
8(36.4)\end{array}$ & 0.862 \\
\hline
\end{tabular}

Strabismus might be the presenting symptom of ONH. In a series with 100 cases with ONH, 68 of the cases had strabismus. Of the 68 patients 32 had esotropia, 23 had exotropia and 8 had vertical strabismus. The strabismus rate was same $(68 \%)$ in unilateral and bilateral ONH groups [12]. In our study, thirteen $(24.1 \%)$ of the 53 cases had esotropia, whereas 20 cases had exotropia (37.8\%) and only 1 case had hypertropia due to inferior oblique overaction.

An unanswered question is whether neuroradiologic investigation and endocrinologic examination is necessary in all cases with ONH. One widely accepted recommendation is that only cases with bilateral ONH, nystagmus, and poor vision should undergo a thorough neuroradiographic and endocrine examination. However, in the present study, the rate of poor vision was not statistically different in cases with isolated ONH and ONH with neurodevelopmental anomalies. Poor vision rate was $38.7 \%$ cases with isolated $\mathrm{ONH}$ and $59.1 \%$ in patients with neurodevelopmental anomalies. Nystagmus rate was also found to be similar in two groups. In other words in cases with neurodevelopmental anomalies $40.9 \%$ of the patients had vision better than logMAR 1.0 or had positive CSM fixation and 54.5\% had no nystagmus. So, to perform neuroimaging in only patients with poor vision and/or nystagmus may cause significant misdiagnoses.

The frequency of endocrine dysfunction in cases with ONH varies considerably from one study to another (13-65\%) $[10,11,15,19,29-31]$. Endocrinologic disorders are serious, and failure to recognize it, carries a risk of adrenal crisis, hypoglycemia, and death [32 - 34]. In a study, in which 55 children with ONH who had been assessed by ophthalmology and endocrine services were reviewed, $49 \%$ of the patients had endocrine dysfunction. They also found that the frequency of endocrinopathy was higher in patients with an abnormal septum pellucidum (56\%) than a normal septum pellucidum (39\%) [13]. Brodsky et al. [32] reported 5 children with septo-optic dysplasia who died suddenly and unexpectedly. All children had corticotropin deficiency, all had thermoregulatory disturbances, and 4 children had diabetes insipidus. They concluded that children with septo-optic dysplasia and hypocortisolism are at risk for sudden death during febrile illness. In our study there were two cases (3.8\%) with growth hormone insufficiency. One of them had ectopic pituitary gland. The other had no recorded pathology on MRI examination. Another case died suddenly. There was no information about endocrinologic investigation in medical records of this patient. Age of this case was 12 months at the last examination and he died 6 months after the last examination. We feel that, the retrospective design of 
our study was the cause for the low rate of the endocrinopathy and it should also be emphasized that endocrinologic evaluation was not routinely performed in our clinical practice.

In conclusion, diagnosis of congenital $\mathrm{ONH}$ is of a great importance because of the genetic and systemic implications. Ophthalmologists are in a unique position to suspect these conditions so that appropriate investigations and therapy can be initiated. In cases with $\mathrm{ONH}$, visual development may be delayed. This means that they may have been perceived as blind in the first few months of life, but that vision improves to a certain extent up to two years of age. The vision of young case with ONH should be monitored at least annually, and any refractive errors should be treated when the visual acuity reaches a functional level. Early surgical correction of strabismus is needed for children who have symmetrical functional vision in the eyes, and thus have some potential for binocularity. Based on the high incidence of structural brain malformations, which may be associated with an increased risk of endocrinopathy and developmental delay, we believe that it is advisable that neuroimaging of the brain, a detailed pediatric neurologic evaluation and endocrinologic evaluation is necessary in all patients with $\mathrm{ONH}$.

\section{CONFLICT OF INTEREST}

The authors confirm that this article content has no conflict of interest.

\section{ACKNOWLEDGEMENTS}

Declared none.

\section{REFERENCES}

[1] Frisen L, Holmegaard L. Spectrum of ONH. Br J Ophthalmol 1978; 62: 7-15. [http://dx.doi.org/10.1136/bjo.62.1.7] [PMID: 629914]

[2] Skarf B, Hoyt CS. ONH in children. Association with anomalies of the endocrine and CNS. Arch Ophthalmol 1984; $102: 62-7$. [http://dx.doi.org/10.1001/archopht.1984.01040030046032] [PMID: 6703969]

[3] Lambert SR, Hoyt CS, Narahara MH. Optic nerve hypoplasia. Surv Ophthalmol 1987; 32(1): 1-9. [http://dx.doi.org/10.1016/0039-6257(87)90069-5] [PMID: 3310293]

[4] Hellstrom A, Wiklund LM, Svensson E. The clinical and morphologic spectrum of ONH. J AAPOS 1999; 3: 212-20. [http://dx.doi.org/10.1016/S1091-8531(99)70005-4] [PMID: 10477223]

[5] Whinery RD, Blodi FC. Hypoplasia of the optic nerve: a clinical and histopathologic correlation. Trans Am Acad Ophthalmol Otolaryngol 1963; 67: 733-8.

[PMID: 14064635]

[6] Mosier MA, Lieberman MF, Green WR, Knox DL. Hypoplasia of the optic nerve. Arch Ophthalmol 1978; 96(8): 1437-42. [http://dx.doi.org/10.1001/archopht.1978.03910060185017] [PMID: 678183]

[7] Hotchkiss ML, Green WR. Optic nerve aplasia and hypoplasia. J Pediatr Ophthalmol Strabismus 1979; 16(4): $225-40$. [PMID: 490275]

[8] Novakovic P, Taylor DS, Hoyt WF. Localising patterns of optic nerve hypoplasia-retina to occipital lobe. Br J Ophthalmol 1988; 72(3): 176-82.

[http://dx.doi.org/10.1136/bjo.72.3.176] [PMID: 3355804]

[9] Hoyt CS, Good WV. Do we really understand the difference between optic nerve hypoplasia and atrophy? Eye (Lond) 1992; 6(Pt 2): 201-4. [http://dx.doi.org/10.1038/eye.1992.39] [PMID: 1624045]

[10] Zeki SM, Hollman AS, Dutton GN. Neuroradiological features of patients with optic nerve hypoplasia. J Pediatr Ophthalmol Strabismus 1992; 29(2): 107-12. [PMID: 1588471]

[11] Brodsky MC, Glasier CM. Optic nerve hypoplasia. Clinical significance of associated central nervous system abnormalities on magnetic resonance imaging. Arch Ophthalmol 1993; 111(1): 66-74. [http://dx.doi.org/10.1001/archopht.1993.01090010070029] [PMID: 8424727]

[12] Garcia ML, Ty EB, Taban M, David Rothner A, Rogers D, Traboulsi EI. Systemic and ocular findings in 100 patients with optic nerve hypoplasia. J Child Neurol 2006; 21(11): 949-56.

[http://dx.doi.org/10.1177/08830738060210111701] [PMID: 17092460]

[13] Birkebaek NH, Patel L, Wright NB, et al. Endocrine status in patients with optic nerve hypoplasia: relationship to midline central nervous system abnormalities and appearance of the hypothalamic-pituitary axis on magnetic resonance imaging. J Clin Endocrinol Metab 2003; 88(11): 5281-6.

[http://dx.doi.org/10.1210/jc.2003-030527] [PMID: 14602762]

[14] Weiss AH, Kelly JP. Acuity, ophthalmoscopy, and visually evoked potentials in the prediction of visual outcome in infants with bilateral optic nerve hypoplasia. J AAPOS 2003; 7(2): 108-15. 
[http://dx.doi.org/10.1016/S1091-8531(02)42004-6] [PMID: 12736623]

[15] Acers TE. Optic nerve hypoplasia: septo-optic-pituitary dysplasia syndrome. Trans Am Ophthalmol Soc 1981; 79 : $425-57$. [PMID: 7043865]

[16] Arslanian SA, Rothfus WE, Foley TP Jr, Becker DJ. Hormonal, metabolic, and neuroradiologic abnormalities associated with septo-optic dysplasia. Acta Endocrinol 1984; 107(2): 282-8. [PMID: 6093418]

[17] De Morsier G. Etudes sur les dysraphies cranio-encephaligues, III: agenesie du septum lucidum avec malformation du tractus optique. La dysplasie septo-optique. Schweiz Arch Neurol Neurochir Psychiatr 1956; 77: 267-92.

[18] Hoyt WF, Kaplan SL, Grumbach MM, Glaser JS. Septo-optic dysplasia and pituitary dwarfism. Lancet 1970; 1(7652): 893-4. [http://dx.doi.org/10.1016/S0140-6736(70)91717-4] [PMID: 4191531]

[19] Siatkowski RM, Sanchez JC, Andrade R, Alvarez A. The clinical, neuroradiographic, and endocrinologic profile of patients with bilateral optic nerve hypoplasia. Ophthalmology 1997; 104(3): 493-6. [http://dx.doi.org/10.1016/S0161-6420(97)30286-3] [PMID: 9082278]

[20] Stanhope R, Preece MA, Brook CG. Hypoplastic optic nerves and pituitary dysfunction. A spectrum of anatomical and endocrine abnormalities. Arch Dis Child 1984; 59(2): 111-4.

[http://dx.doi.org/10.1136/adc.59.2.111] [PMID: 6703761]

[21] Edwards WC, Layden WE. Optic nerve hypoplasia. Am J Ophthalmol 1970; 70(6): 950-9. [http://dx.doi.org/10.1016/0002-9394(70)92474-8] [PMID: 5530951]

[22] Walton DS, Robb RM. Optic nerve hypoplasia. A report of 20 cases. Arch Ophthalmol 1970; 84(5): 572-8. [http://dx.doi.org/10.1001/archopht.1970.00990040574003] [PMID: 5478881]

[23] Jan JE, Robinson GC, Kinnis C, MacLeod PJ. Blindness due to optic-nerve atrophy and hypoplasia in children: an epidemiological study (1944-1974). Dev Med Child Neurol 1977; 19(3): 353-63. [http://dx.doi.org/10.1111/j.1469-8749.1977.tb08372.x] [PMID: 560328]

[24] Petersen RA, Walton DS. Optic nerve hypoplasia with good visual acuity and visual field defects: a study of children of diabetic mothers. Arch Ophthalmol 1977; 95(2): 254-8. [http://dx.doi.org/10.1001/archopht.1977.04450020055011] [PMID: 836211]

[25] Björk A, Laurell CG, Laurell U. Bilateral optic nerve hypoplasia with normal visual acuity. Am J Ophthalmol 1978; 86(4): 524-9. [http://dx.doi.org/10.1016/0002-9394(78)90301-X] [PMID: 707598]

[26] Strömland K, Hellström A. Fetal alcohol syndrome-an ophthalmological and socioeducational prospective study. Pediatrics 1996; 97(6 Pt 1): 845-50. [PMID: 8657525]

[27] Weiss AH, Ross EA. Axial myopia in eyes with optic nerve hypoplasia. Graefes Arch Clin Exp Ophthalmol 1992; $230(4): 372-7$. [http://dx.doi.org/10.1007/BF00165948] [PMID: 1505771]

[28] Zion V. Optic nerve hypoplasia. Ophthalmic Semin 1976; 1(2): 171-96. [PMID: 799278]

[29] Phillips PH, Spear C, Brodsky MC. Magnetic resonance diagnosis of congenital hypopituitarism in children with optic nerve hypoplasia. J AAPOS 2001; 5(5): 275-80. [http://dx.doi.org/10.1067/mpa.2001.118220] [PMID: 11641635]

[30] Costin G, Murphree AL. Hypothalamic-pituitary function in children with optic nerve hypoplasia. Am J Dis Child 1985; 139(3): 249-54. [PMID: 2983530]

[31] Sorkin JA, Davis PC, Meacham LR, Parks JS, Drack AV, Lambert SR. Optic nerve hypoplasia: absence of posterior pituitary bright signal on magnetic resonance imaging correlates with diabetes insipidus. Am J Ophthalmol 1996; 122(5): 717-23. [http://dx.doi.org/10.1016/S0002-9394(14)70492-1] [PMID: 8909213]

[32] Brodsky MC, Conte FA, Taylor D, Hoyt CS, Mrak RE. Sudden death in septo-optic dysplasia. Report of 5 cases. Arch Ophthalmol 1997; 115(1): 66-70. [http://dx.doi.org/10.1001/archopht.1997.01100150068011] [PMID: 9006427]

[33] Cameron FJ, Khadilkar VV, Stanhope R. Pituitary dysfunction, morbidity and mortality with congenital midline malformation of the cerebrum. Eur J Pediatr 1999; 158(2): 97-102. [http://dx.doi.org/10.1007/s004310051026] [PMID: 10048603]

[34] Gilbert JD, Scott G, Byard RW. Septo-optic dysplasia and unexpected adult death-an autopsy approach. J Forensic Sci 2001; 46(4): 913-5. [http://dx.doi.org/10.1520/JFS15068J] [PMID: 11451077]

Received: April 1, $2015 \quad$ Revised: October 19, 2015

Accepted: October 25, 2015

(C) Eyyup Karahan and Ayse Tulin Berk; Licensee Bentham Open.

This is an open access article licensed under the terms of the Creative Commons Attribution-Non-Commercial 4.0 International Public License (CC BY-NC 4.0) (https://creativecommons.org/licenses/by-nc/4.0/legalcode), which permits unrestricted, non-commercial use, distribution and reproduction in any medium, provided the work is properly cited. 